\title{
Improving the Competitive Advantage of BUMDes Based on The Optimal Utilization of Local Assets Communities
}

\author{
Condro Puspo Nugroho ${ }^{1 *}$, Vi'in Ayu Pertiwi², Deny Meitasari², Destyana Ellingga Pratiwi ${ }^{3}$ \\ Department of Socio-Economics, Faculty of Agriculture, Brawijaya University, Veteran St., Malang, \\ (65145), Indonesia
}

Received: 4 December 2019; Revised: 22 July 2020; Accepted: 23 November 2020

\begin{abstract}
BUMDes is one of the income sources for the village managing assets, services, and other businesses for the village community's welfare. BUMDes empowers rural communities as an autonomous region in increasing productive efforts to alleviate poverty and unemployment. Therefore, the measurement of BUMDes's performance needs to be done through the level of local resources used and the implications of the results achieved. It was required to formulate appropriate development policies so that BUMDes have high competitiveness and fulfill their role in increasing the community's economic independence. This study was conducted in East Java BUMDes because East Java province is the third province with the largest number of BUMDes in Indonesia, so it was quite representative to represent the presence of BUMDes in Indonesia. This research used a quantitative approach carried out using the structural equation modelingpartial least square (SEM-PLS) method with the Resource-based View (RBV) approach to measure the effect of BUMDes resources used on its competitiveness. The analysis showed that structural capital had a positive effect on human capital and relational capital. Human capital had also been proven to have a positive effect on relational capital. The indicator that influenced competitive advantage was human capital. Training is needed to increase the human resources capacity, online marketing training and organizational reform, infrastructure, and professional management systems need to be done.
\end{abstract}

Keywords: BUMDes; independence; welfare; SEM-PLS

\section{How to Cite:}

Nugroho, C. P., Pertiwi, A., Meitasari, D., \& Pratiwi, D. E. (2020). Improving the Competitive Advantage of BUMDes Based on The Optimal Utilization of Local Assets Communities. HABITAT, 31(3), 161168. https://doi.org/10.21776/ub.habitat.2020.031.3.19

\section{Introduction}

The rural economy is more dominated by the agricultural sector, mainly because rural areas are generally suitable for agricultural activities due to the habits and traditions owned by rural residents that make farming as the primary income. This condition becomes the main reason business orientation formation is generally still subsistence in which its production activities do not focus on gaining profit but only on fulfilling their daily needs. Therefore, rural economic growth tends to be slower than urban economic growth. Based on this fact, rural development needs to be conducted.

Village-Owned Enterprises (BUMdes) defines an institution formed by the village

*Penulis Korespondensi

E-mail: condro@ub.ac.id government and managed by the community based on the village's needs and economy. BUMdes is developed based on legislation that applies to the agreement between villagers. The purposes of BUMdes are increasing and strengthening the rural economy. BUMdes functions as a commercial institution offering local resources aimed to seek profits and a social institution providing social services for the community's benefit. BUMdes creates positive contributions to strengthen the rural economy in developing the community's economy, especially in facing the ASEAN Economic Community 2015 (Alkadafi, 2014).

Therefore, BUMDes' performance needs to be measured through the local resources used and the implications of the results achieved. Both discussions are necessary to formulate the right development policy so that BUMDes has high competitiveness and fulfills its role in increasing the farmers' economic independence.

Available online at HABITAT website: http://www.habitat.ub.ac.id ISSN: 0853-5167 (p); 2338-2007 (e) 
The efficiency and effectiveness principles must be emphasized in carrying out business. BUMdes is a legal entity formed based on applicable laws and regulations and adapted to the village community's agreement. Thus, in Indonesia, there are various forms of BUMDes based on the local characteristics, potentials, and resources owned by each village (Development System Dynamics Study Center,2007). The most common form of BUMdes is an agricultural business, and the rest is engaged in services and trades.

Furthermore, the formation of BUMDes also has its obstacles that caused efforts in improving the welfare of the village community may not effective. The field condition shows that not all BUMDes that established successfully achieve their goals. Ferreira et al. (2011) stated that a company's success is highly determined by the resources owned and the capabilities of companies that can change the resources into an economic benefit. Additionally, Barney (2007) argued that the company's resources, which consist of human, structural, and relational capital, are needed to achieve a sustainable competitive advantage. The utilization of less optimal resources is the main factor of slow or cessation development of BUMDes. Based on the ResourceBased View theory, specifically, the village must have these valuable, rare, non-substituted, and non-imitated resources (Barney, 1991). According to those problems, this study aimed to identify the most influential resources in the competitive advantage, specifically in agricultural-based BUMDes in East Java.

\section{Research Methodology}

The research unit sample was agriculture based BUMDES in East Java by including the management/managers and members, village government, residents, and several agencies related to the implementation of Bumdes as key informants in each sample of BUMDes. The business unit's establishment should be discussed in the Musdes Forum (highest power to BUMDES) because each business unit formed contained a risk (Sutoro et al., 2013).

This study used primary data type. The data collection was done by doing observation, personal interview, and focus group discussion. The study was conducted in July - October 2019. The Structural Equation Modeling - Partial Least Square (SEM-PLS) method with the ResourceBased View (RBV) approach used for data analysis in measuring the effects of BUMDes resources on its competitiveness. Some variables used in this study were Human, Structural, and Relational Capital. Estimating PLS-SEM was component-based and flexible that prioritized predictions allegedly without the need for normal distribution assumptions (Zuhdi, 2016).

\section{Results and Discussions}

\subsection{The Condition of BUMDes in East Java}

BUMDes became the economic driven for people. The operational activities accommodated the economic activities of the community managed professionally by the management. In 2019 , the data showed that there were 2,673 units of BUMDes spread in East Java. According to its business unit, most BUMDes were engaging in savings and loans, tourism, trade, and livestock. Trading is a business managed by BUMDes included shops and trading involved in nine primary food areas, while farms for livestock were almost $63 \%$ of the business units were goat farms. The specific findings to business units in East Java dominated by mixer truck rental with $40 \%$ out of the entire rental business. The need for clean water also raised the existence of HIPAM (Himpunan Pengusaha Air Minum).

The savings and loan business units were still popular, considering that village communities need access to capital for running business activities. Besides, this business unit was relatively easy to do compared to other business units. The tourism business unit also reached $14 \%$ of all BUMDes business units. Due to the regional potential-based, many tourism business units appeared because of many and varied tourist destinations located in East Java.

In line with data from East Java Province, the data of BUMDes business unit in Malang Regency also showed that out of 139 business units, most of the business units managed by BUMDes were savings and loan, trading, tourism, and HIPAM. Meanwhile, the rest were management business units such as waste, agriculture, livestock, services, TPST, village markets, and BNI agents 46. Most of the trading business units were shops and groceries. It was appealing that the business units related to water management reach $17 \%$ of the total business units managed by BUMDes. It showed that the need for clean water by the community in Malang Regency was very high. 
BUMDes formed to bridge the village government and the community in improving the economy based on potential village management. Of the many BUMDes business units, the most developed was the tourism sector. It was natural since people tended to form business units based on the natural potential of the area. Even the existence of business units in the tourism sector might accelerate the development of BUMDes. For instance, a village with some natural potentials, namely beaches and marine products, would become a tourist attraction. On the other hand, many businesses grew from tourist attractions, namely culinary, transportation, lodging, and unique souvenirs. It made BUMDes became a social-economic platform that encouraged strength and created independence for the village economy.

One example of a tourism business unit managed by a successful Bumdes in the Malang Regency was Pujon Kidul Tourism Village. Through the management of BUMDes Sumber Sejahtera, Pujon Kidul Tourism Village gained 14 billion turnovers per year. The local community carried out the management based on its potential in a cool and beautiful rural atmosphere attracting tourists to visit and spend more time there. The operation of BUMDes Sumber Makmur in Pujon Village displayed many improvements, such as the appearance of innovations and continuously increasing business units, for instance, Café Sawah. It was in the middle of rice fields with mountains as views. Pujon Kidul Tourism Village management could be an excellent example of the success in managing tourism business units through BUMDes management. It portrayed that BUMDes was able to be one of the alternatives in developing the territory potential and resolving the unemployment issues faced by the village community.

\subsection{The Use of the Most Influential Resources towards the Competitive Advantage of BUMDes}

\subsubsection{Measurement Model Testing (Outer Model)}

The convergent and discriminant validity was evaluated using the outer measurement model. Convergent validity assessed by looking at the reliability of indicators, Composite Reliability, and Average variance extracted. Data validity testing and reliability conducted using the Partial Least Square software. The number of indicators or question items in the questionnaires were 24 questions. Based on the testing of validity and reliability of questions, 20 items declared as valid.

\section{a. Formative Model Evaluation}

Based on its relationship with indicators/measurement variables, latent variables used in this study consisted of two types, namely formative and normative models. The Human Capital (HC) and Structural Capital (SC) variables had a formative relationship with the indicator variables because the indicator variables used in this study were the formers of the $\mathrm{HC}$ and SC variables. According to Solimun, Fernandes, and Nurjannah (2017), the evaluation of formative models measured by indicators of reliability and collinearity. The reliability indicators could be seen from the significant weight value; the value of the P-value must be less than $0.05 \quad(<0.05)$. Collinearity was visible from the value of the variance inflation factor (VIF) with VIF provisions $<3.3$. The following was the value of Indicator Weight in this study.

Table 1. Indicator Weights Values

\begin{tabular}{lllll}
\hline Variable & HC & SC & VIF & p-value \\
\hline $\mathrm{HC}_{2}$ & 0,603 & & 1,405 & $<0,001$ \\
$\mathrm{HC}_{3}$ & 0,315 & & 1,006 & 0,015 \\
$\mathrm{HC}_{4}$ & 0,591 & & 1,043 & $<0,001$ \\
$\mathrm{SC}_{2}$ & & 0,624 & 1,087 & $<0,001$ \\
$\mathrm{SC}_{4}$ & & 0,624 & 1,087 & $<0,001$ \\
\hline
\end{tabular}

The data from Table 1. displayed each indicator on the formative variable had a p-value less than 0.05, and the VIF value was less than 3.3. Thus, the formative variable indicator was reliable because it qualified the indicator reliability and did not indicate the problem of collinearity.

\section{b. Reflective Model Evaluation}

According to Solimun, Fernandes, and Nurjanah (2017), the convergent validity measured using the loading factor for the reflective model and the component loading for the formative model.

Based on Table 2, all the indicators in the measurement model evaluation had met the criteria and were declared valid. According to Sholihin and Ratmono (2013), the loading requirement must be above 0.70 because latent variables should explain each indicator's variation of $50 \%$. If the loading factor was over 0.70 and the loading factor was below 0.40 , the reflective indicator was removed. The value of loading factors in the overall study was above 0.70 . So, it meant that the value of loading factors and 
Average Variance Extracted (AVE) following the criteria.

Table 2. The Outer Model of Convergent Validity

\begin{tabular}{|c|c|c|c|}
\hline & $\begin{array}{l}\text { AVE } \\
\text { Value }\end{array}$ & $\begin{array}{l}\text { Loading } \\
\text { factor }\end{array}$ & p-value \\
\hline $\begin{array}{l}\text { Standard } \\
\text { Value }\end{array}$ & $>0,5$ & 0,7 & $<0,05$ \\
\hline $\begin{array}{l}\text { Relational } \\
\text { Capital (RC) }\end{array}$ & & & \\
\hline $\begin{array}{l}\mathrm{RC}_{1} \\
\mathrm{RC}_{2}\end{array}$ & 0,773 & $\begin{array}{l}0,879 \\
0,879 \\
\end{array}$ & $\begin{array}{l}<0,001 \\
<0,001 \\
\end{array}$ \\
\hline $\begin{array}{l}\text { Competitive } \\
\text { Advantage } \\
\text { (KB) }\end{array}$ & & & \\
\hline $\begin{array}{l}\mathrm{KB}_{1} \\
\mathrm{~KB}_{2} \\
\mathrm{~KB}_{3}\end{array}$ & 0,566 & $\begin{array}{l}0,912 \\
0,489 \\
0,792\end{array}$ & $\begin{array}{l}<0,001 \\
<0,001 \\
<0,001\end{array}$ \\
\hline
\end{tabular}

The AVE value limit was 0.50 , while the $\mathrm{p}$ value was $<0.05$ (Solihin and Ratmono, 2013). The P-Value of this study in all indicators showed value $<0.05$. It displayed that this study had good convergent validity due to the loading factor, $\mathrm{p}$ value, and AVE values had met the criteria described above.

\section{c. Discriminant Validity Testing}

The discriminant validity was tested by comparing the root values of the Average Variance Extracted (AVE) of each construct with the correlation between constructs and other constructs. The construct was declared as valid if the AVE's root value was greater than the correlation between constructs and other constructs. Table 3 below showed the AVE and the roots of AVE. Also, table 4 displayed the correlation between constructs and other constructs.

Table 3. Average variance extracted (AVE) and The Root of Average Variance Extracted (AVE)

\begin{tabular}{llll}
\hline & & AVE & $\begin{array}{l}\text { The } \\
\text { Root } \\
\text { of } \\
\text { No. }\end{array}$ \\
& & Variable & AVE \\
\hline 1 & Structural Capital (SC) & 0,302 & 0,549 \\
2 & Human Capital (HC) & 0,402 & 0,634 \\
3 & Relational Capital (RC) & 0,411 & 0,641 \\
4 & $\begin{array}{l}\text { Competitive Advantage } \\
\text { (KB) }\end{array}$ & 0,748 & 0,865 \\
\hline
\end{tabular}

Table 3 showed the root value of AVE for the Structural Capital (SC) construct of 0.549.
Meanwhile, the correlation between the SC construct and "other constructs" shown in the table as follows: the correlation between SC and Human Capital (HC) of 0.345, with a Relational Capital (RC) of 0.412, with Competitive Advantage (KB) of 0.265 .

These results indicated that AVE's root values were more significant than the correlation between constructs $(0.549>0.345 ; 0.412$; and $0.265)$. Therefore, the SC construct was declared as valid (Ghozali, 2006).

Table 4. Intervariable Correlation Constructs

\begin{tabular}{lcccc}
\hline Variable & SC & HC & RC & KB \\
\hline $\begin{array}{l}\text { Structural } \\
\text { capital (SC) }\end{array}$ & 1,000 & & & \\
$\begin{array}{l}\text { Human } \\
\text { capital (HC) }\end{array}$ & 0,345 & 1,000 & & \\
$\begin{array}{l}\text { Relational } \\
\text { capital (RC) }\end{array}$ & 0,412 & 0,525 & 1,000 & \\
$\begin{array}{l}\text { Competitive } \\
\text { Advantage }\end{array}$ & 0,265 & 0,553 & & 1,000 \\
(KB) & & & & \\
\hline
\end{tabular}

The HC construct in Table 10 showed 0.634 for the root value of AVE. While the correlation between variable $\mathrm{HC}$ and $\mathrm{KB}$ was 0.553 , between $\mathrm{HC}$ and $\mathrm{RC}$ was 0.525 , between $\mathrm{HC}$ and $\mathrm{SC}$ was 0.345 . Because AVE's root value was greater than the correlation between constructs, the constructs of $\mathrm{HC}$ were valid $(0.634>0.553 ; 0.525$; and 0.345 ).

The root value of AVE for RC construct was 0.641 . Meanwhile, the correlation between $\mathrm{RC}$ and $\mathrm{KB}$ constructs was 0.505 , with $\mathrm{SC}$ was 0.412 and $\mathrm{HC}$ was 0.525 . From these results, it was clear that AVE's root value was greater than the correlation of each construct $(0.641>0.505$; 0.412 and 0.525 ), the RC construct declared as valid.

The Discriminant Validity test of KB construct showed that the root value of AVE was 0.865 . While the inter-constructs correlations were as follows: $\mathrm{KB}$ with $\mathrm{SC}$ of 0.265 , with $\mathrm{HC}$ of 0.553 , and with $\mathrm{RC}$ of 0.505 . In short, $\mathrm{KB}$ constructs were valid due to AVE's root values were more significant than the correlation between each construct $(0.865>0.265 ; 0.553$; and 0.505$)$.

To sum up, all constructs in this study: Structural Capital (SC), Human Capital (HC), Relational Capital (RC), and Competitive Advantage (KB) had a more excellent AVE root value of the correlation between constructs, which meant it met the criteria for discriminant validity. 


\section{d. Composite Reliability Testing}

The Evaluation of the (Outer) model measurement might also be seen from other tests, namely the Composite Reliability of the indicator block that measured the construct. The results of the composite reliability for each construct presented in table 5 .

Table 5. Composite reliability

\begin{tabular}{ll}
\hline Variable & $\begin{array}{l}\text { Composite } \\
\text { reliability }\end{array}$ \\
\hline Structural capital (SC) & 0,682 \\
Human capital (HC) & 0,664 \\
Relational capital (RC) & 0,787 \\
Competitive Advantage & 0,772 \\
(KB) &, \\
\hline
\end{tabular}

Table 5 displayed all the reliable constructs. It showed from the composite reliability values in which the value of constructs for $\mathrm{HC}$ was 0.664 , for $\mathrm{RC}$ was 0.787 , and for $\mathrm{KB}$ was 0.772 .
Otherwise, the construct reliability also supported by the value of $t_{\text {count }}$ was greater than $t_{\text {table }}$ by $>$ 1.96 .

\section{e. Structural Model Testing (Inner Model)}

The structural model (inner) was evaluated using R-square for the dependent construct. The measuring model was defined as the inter latent constructs relationship evaluation hypothesized in this study with results as follows.

Table 6. R-square Values

\begin{tabular}{ll}
\hline Variable & R-square \\
\hline Structural capital (SC) & - \\
Human capital (HC) & 0,089 \\
Relational capital (RC) & 0,444 \\
Competitive Advantage (KB) & 0,610 \\
\hline
\end{tabular}

The results of testing with Partial Least Square research model were a tiered regression equation model with hypothesis testing 1 to 6 explained in Table 7 below.

Table 7. The Results of Inner Model and T-Value

\begin{tabular}{lllll}
\hline Hypothesis & Estimate & $\begin{array}{l}\text { Standard } \\
\text { deviation }\end{array}$ & t-value & Information \\
\hline H1: SC affected HC & 0,345 & 0,364 & 2,574 & Accepted \\
H2: SC affected RC & 0,262 & 0,275 & 2,078 & Accepted \\
H3: HC affected RC & 0,434 & 0,427 & 3,273 & Accepted \\
H4: SC affected KB & 0,007 & $-0,008$ & 0,064 & Rejected \\
H5: HC affected KB & 0,295 & 0,277 & 2,258 & Accepted \\
H6: RC affected KB & 0,148 & 0,179 & 1,163 & Ditolak \\
\hline
\end{tabular}

The hypotheses testing presented above discussed in the next sub-chapter.

\subsubsection{The Hyphotheses Testing}

\section{a. H1: Structural Capital Affected Human Capital}

Based on hypothesis testing results, the estimate's value was positive with a significance level of $5 \%$. An optimistic estimate value indicated that the structural capital variable influenced human capital. These results showed that the first hypothesis was accepted. The higher the structural capital, the higher the human capital would be. It presented that if the structural capital increased, its human capital would also increase. As stated by Bontis et al. (2000), the structural capital could consist of non-human assets and organizational capabilities. The structural capital was significant for an organization such as BUMDes considering that not only one business unit that was covered and able to absorb quite a lot of workforce, but also those who were members of the BUMDes organization management and worked in the BUMDes business unit. The existence of structural capital support in distributing work tasks, databases, software, hardware availability, and other facilities would increase the individual's experiences, skills, and motivation as the BUMDes members to improve their competence, attitudes, and intellectual intelligence.

\section{b. H2: Structural Capital Affected Relational Capital}

The hypothesis testing results displayed that the estimate's value was positive, with a significance level of $5 \%$. This positive and significant estimate value showed that the structural capital influenced the relational capital. So, the second hypothesis was accepted. As the previous hypothesis explained, the structural capital tended to be non-human capital and organizational capabilities, or physical facilities owned by the organization. Therefore, it was 
natural when structural capital affects relational capital. The relational capital was defined as knowledge gained from the marketing channels and external networking with customers, suppliers, government, or other parties related to BUMDes. Hence, with the high support of structural capital, the relational capital of the BUMDes organization would be higher as well. Every non-human capital and organizational capabilities enhancement in the form of organizational structures. The existence of tasks division would increase the diversity involved in carrying the task so that togetherness was needed. The database, strategy, and implementation procedures of every activity would make it easier to engage with other parties to become customers or potential partners so the relational capital could increase in either organization or the BUMDes unit.

\section{c. H3: Human Capital Affected Relational Capital}

Based on the hypothesis testing results, the estimate's value was positive and significant at the level of 5\%. It showed Human Capital affected Relational Capital. So, the third hypothesis was accepted. Therefore, the increasing human capital in a BUMDes organization would increase the relational capital as well. In this study, human capital covered some individual knowledge such as experiences, skills, motivation, and tolerance towards ambiguity, which formed through intellectual competence, attitudes, and intelligence. It indicated that the high level of knowledge, experience, skills, motivation, and individual tolerances owned by the BUMDes members would significantly affect the relational capital. The height of the human capital held by the BUMDes organization would helpfully improve the convenience of customers and potential parties that established cooperation so that everything could run well.

\section{d. H4: Structural capital Affected Competitive Advantage}

Based on the hypothesis testing results, the estimated value was positive and not significant at the level of 5\%. In short, structural capital did not affect competitive advantage. This fourth hypothesis indicated that the hypothesis was rejected. Structural Capital was a non-human knowledge in BUMDes organization, including databases, organizational structures, process instructions, strategies, routines, software, hardware, and others valued higher than materials.
It displayed that the structural capital variable did not directly affect the competitive advantage. Business benefits, turnover, market share, and customer loyalty, were not directly influenced by structural capital, which supported the organization's physical facilities, such as the organizational structure, database, and others.

In the context of either an institution or higher institutions, the structural capital was possible to be a driver of competitiveness. In which the TARIFF principle (transparency, accountability, responsibility, independence, fairness) in the GCG principle (good corporate governance) performed as a whole. Migrating to a behavior and culture Institution, so could be a guide to increase the added value.

The competitive advantage was driven by social, human, and financial capital. Social capital was related to relations between people in organizations (internal social capital) as well as between organizations and outsiders (external social capital) (De Massis et al., 2011).

\section{e. H5: Human capital Affected Competitive Advantage}

Based on the hypothesis testing results, the estimate's value was positive and significant at the level of 5\%. It indicated Human Capital affected competitive advantage. The increasing of human capital would be followed by the increasing of competitive advantage in the organization. Shortly, the fifth hypothesis was accepted. Human Capital covering individual knowledge owned by BUMDES organizations, including experience, skills, motivation, tolerance to ambiguity produced through competence, attitudes, and intelligence, would significantly affect the high competitiveness of the BUMDes organization. The higher the skills, experience, knowledge, and motivation of the administrators and members of BUMDes in each business unit, would increase competing superiority, such as business profits, business and capital turnover used, and market share were increasingly diverse. It would undoubtedly be followed by customer loyalty in every business unit.

\section{f. H6: Relational capital Affected Competitive Advantage}

This sixth hypothesis testing showed that the estimate's value was positive but not significant so that the hypothesis was rejected. The relational capital did not affect competitive advantage even though the estimate's value was positive. Relational capital did not directly affect 
competitive advantage since relational capital was shown in marketing channels and organizations' external relationships with customers, suppliers, government, or other parties related to the organization. While the relationship between organizations and business units and BUMDes did not directly affect competitive advantages such as business profit, business turnover, and others. Competitive advantage was more influenced by human capital, who were members of the BUMDES organization.

\subsubsection{The Use of the Most Influential Resources towards the Competitive Advantage}

Based on the relationship between resources used, Figure 1. described the use of the most influential resources towards competitive advantage. Human Capital might directly affect competitive advantage, while structural capital must pass through Human Capital to influence competitive advantage.

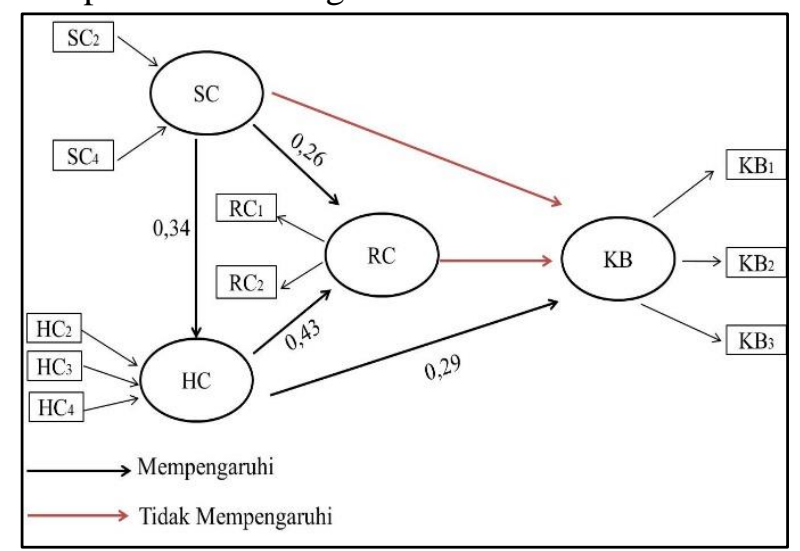

Information:

SC : Structral Capital

$\mathrm{SC}_{2}$ : Environment

HC : Human Capital

$\mathrm{SC}_{4}$ : Organizational

$\mathrm{RC}$ : Relational Capital

Structure

$\mathrm{KB}$ : Competitive $\mathrm{RC}_{1}$ : Relation between Advantage

Costumers

$\mathrm{HC}_{2}$ : Organizational

Culture

$\mathrm{RC}_{2} \quad$ : Market

$\mathrm{HC}_{3}$ : Relation between

Staffs

Development

$\mathrm{KB}_{1}$ : Profitability

$\mathrm{HC}_{4}$ : Work Ethic

$\mathrm{KB}_{2}$ : Business Turnover

$\mathrm{KB}_{2}$ : Market Share

Figure 1. The Relations between Resources to Competitive Advantage of BUMDes

The Structural Capital support was the modal for strengthening the Human Capital. The existence of organizational structures for distributing the main tasks of work, databases, software, and hardware availability, also other facilities would enhance the experience, skills, knowledge and motivate individuals who were members of the BUMDes organization. It was needed to improve their competence, attitudes, and intellectual intelligence so the competitive advantage would increase and reflect in the profitability of business, turnover, and market share enhancement. It proved that human capital could be associated with high dedication and commitment (Cabrera-Suarez et al., 2001).

\section{Conclusion}

The data of East Java Province DPMD in 2017 indicated that East Java was the third province with the highest number of BUMDes in Indonesia, which was 1,424 units (7.7\%). BUMDes, as one of the village's original income sources, was expected to manage assets, services, and other businesses for maximalizing the village community's welfare. The use of resources that directly affected competitive advantage was Human Capital, while the resource that indirectly affected competitive advantage was Structural Capital.

\section{References}

Alkadafi, M. (2014). Penguatan Ekonomi Masyarakat melalui Pengelolaan Kelembagaan Badan Usaha Milik Desa menuju ASEAN Economic Community 2015. Jurnal El- Riyasah, 5(1), 3pp.2-40.

Barney, Jay. (1991). Firm Resource and Sustained Competitive Advantage. Journal of Management, 17, pp.99-120.

Barney, Jay. (2007). Gaining and Sustaining Competitive Advantage: 3ed. Pearson International Education Inc., Publishing as Prentice Hall Upper Saddle River, New Jersey, 07458, USA.

Cabrera-Suarez, K., De Sea-Perez, P. and GarciaAlmeida, D. (2001). The succession process from a resource-and knowledge based view of the family firm. Family Business Review, pp. 14- 37.

De Massis, A., Federico, F., Pizzurno, E. and Cassia, L. (2011). Product innovation in family vs non-family firms: an exploratory analysis. Journal of Small Business Management. Vol. 53 No. 1, pp.1-36.

Ferreira, J.J; Azevedo, G.S dan Fernandez, R. (2011). Contribution of resource based view and entrepreneurial orientation on small firm growth. Cuadernos de Gestin, Vol 11, no. 1, pp.95-104. 
Pusat Kajian Dinamika Sistem Pembangunan. (2007). Buku Panduan Pendirian dan Pengelolaan Badan Usaha Milik Desa (BUMDes). Malang: Fakultas Ekonomi Universitas Brawijaya.

Solimun, Fernandes, A. A. R., \& Nurjannah. (2017). Metode Statistik Multivariat Permodelan Persamaan Struktural (SEM) Pendekatan WarpPLS (Pertama). Malang: UB Press.

Sutoro, Eko bersama Tim FPPD. (2013). Policy Paper. Membangun BUMDes yang Mandiri, Kokoh dan Berkelanjutan. Trevinyo-Rodriguez, R. N. and Tapies, J., (2006). Effective knowledge transfer in family firms.

Zuhdi, B. Suharso, H. S. (2016). Perbandingan pendugaan parameter koefisien model struktural melalui SEM dan PLS-SEM. Jma, 15, pp.11-2. 